\title{
Inhibitory Effects of Zerumbone on MCP-1-Induced THP-1 Migration
}

\author{
Sa Hyun Kim¹, Si Hyun Kim ${ }^{1}$, Sung Ryul Ryu ${ }^{1}$, Pyeongjae Lee ${ }^{2}$, Cheol Moon ${ }^{1}$
}

\section{MCP-1에 의해 유도된 THP-1 유주에 미치는 Zerumbone의 영향}

김사현 ${ }^{1}$, 김시현 ${ }^{1}$, 유성률 ${ }^{1}$, 이평재 ${ }^{2}$, 문 철 ${ }^{1}$

${ }^{1}$ 세명대학교 임상병리학과, ${ }^{2}$ 세명대학교 자연약재학과

\begin{abstract}
This study examined the effects of zerumbone on monocyte migration. Monocytes are recognized as important mediators of various inflammatory diseases, and the possibility of controlling inflammatory diseases by regulating the monocyte functions, such as activity and mobility, has been reported. MCP-1, which is a chemokine with levels that increase upon inflammation, causes the migration of the monocyte cell line, THP-1. Migration occurred at a concentration of $10 \mathrm{ng} / \mathrm{mL}$ MCP-1, and the highest migration occurred at $100 \mathrm{ng} / \mathrm{mL}$ and $200 \mathrm{ng} / \mathrm{mL}$. MCP-1-induced THP-1 migration decreased by more than $40 \%$ in the presence of zerumbone. The concentration of CAMP, an important secondary messenger of the CCR2 signaling pathway, the MCP-1 receptor, was increased in the culture medium after a zerumbone treatment. The concentrations of CAMP decreased significantly under the MCP-1 treatment condition only. On the other hand, an increase in CAMP was observed when zerumbone and $\mathrm{MCP}-1$ were treated simultaneously. Erk phosphorylation induced by an MCP-1 treatment was also found to decrease with the zerumbone treatment. This study introduces the possibility of controlling inflammatory diseases through the function of zerumbone, which regulates the migration of monocytes.
\end{abstract}

Key words: Migration, Monocyte, Monocyte chemoattractant protein 1, Zerumbone

This is an Open Access article distributed under the terms of the Creative Commons Attribution Non-Commercial License (http://creativecommons.org/licenses/by-nc/4.0) which permits unrestricted non-commercial use, distribution, and reproduction in any medium, provided the original work is properly cited.

Copyright (c) 2018 The Korean Society for Clinical Laboratory Science. All rights reserved.
Corresponding author: Cheol Moon Department of Clinical Laboratory Science, Semyung University, 65 Semyung-ro, Jecheon 27136, Korea

Tel: 82-43-649-1419

Fax: 82-43-649-1419

E-mail: antigene@semyung.ac.kr

Received: May 9, 2018

Revised: May 21, 2018 Accepted: May 22, 2018

\section{서 론}

단구는 골수에서 생성되는 혈구로써 선천면역계를 구성하는 주요 세포다. 혈액을 따라 신체를 순환하며 탐식 기능 수행 뿐 아 니라, 조직으로 유주(migration)한 후에는 다양한 대식세포 혹 은 수지상세포로 분화하여 조직에 침투한 외부 감염 인자 탐식, 조직 항상성 유지 등의 기능을 발휘한다. 수지상세포는 외부 인 자 탐식 후 T림프구에게 항원을 제시하여 선천면역과 후천면역
의 매개자로써 역할을 수행한다. 그러므로, 단구의 활성과 기능 에 대한 지식은 면역반응 전체를 이해하는 중요한 시작점이 된 다. 나아가 단구의 활성과 기능을 강화 혹은 제어할 수 있는 기전 을 통해 외부 침입 인자에 대한 방어를 강화하거나 면역반응을 조절할 수 있을 것으로 여겨진다. 최근에는 단구와 죽상동맥경 화증(atherosclerosis) 같은 염증 질환과의 관계가 연구되면서, 단구가 만성 - 급성 염증질환의 매개자로 인식되고 있다[1].

야생 생강의 일종인 Zingiber zerumbet Smith의 정유 
(essential oil)에 포함되어 있는 주요 성분인 zerumbone은 혈 액종양을 포함한 암세포 죽음, 염증 및 활성산소 감소 등에 기여 할 수 있음이 보고 되었다[2-4]. 또한 면역세포들의 증식과 세포 주기진행, 사이토카인의 생성·발현에도 효과를 나타낸다고 알 려져 있다[5]. 이외에도 간보호, 통증완화, 항동맥경화, 항미생 물 등 zerumbone의 다양한 생물학적 기능이 보고되었다[6-9]. 특히, 신장상피세포암 세포주를 이용한 이종이식 모델 연구를 통해 zerumbone이 암세포의 증식, 생존, 혈관형성을 억제하는 기능이 있음이 보고되었다. 이와 같은 zerumbone의 항암 효능 은 STAT3의 활성을 저하시킴으로써 나타난다[10]. 또한, zerumbone은 p53신호전달 과정을 활성화 시켜 췌장 상피암 세포의 자가사멸을 유도하였다[11]. 이외에도 간암, 위암, 피부 암, 담도암 등 다양한 암세포의 세포자멸사 유발, 전이 방지 효 능을 나타내는 것으로 알려져 있다. 아울러, 항염증 효능도 보고 되었는데, dextran sodium sulfate (DSS) 유발 급성궤양성장 염 증세가 zerumbone 식이를 통해 호전되었으며[12], 콜라겐 유발 관절염 모델 렛트에게 zerumbone 화합물을 먹인 후에 증 세가 호전되었다는 보고도 있다[13]. Zerumbone은 면역조절 기능도 지니고 있음이 보고되었다. 마우스의 흥선세포와 비장 세포의 증식이 zerumbone에 의해 더욱 강화되었으며, 사람 말 초혈액 단핵세포(peripheral blood mononuclear cell, PBMC) 의 증식 역시 zerumbone에 의해 증가됨이 보고 되었다. 또한, zerumbone이 G2/M 세포주기 집중현상, 그리고, interleukin $\mathrm{IL}-2, \mathrm{IL}-12$ 생성/분비 증가를 유발함이 보고되었다[5]. 아울 러, SDF- $1 \alpha$ 에 의해 유도된 T세포주 Jurkat cell의 유주 현상이 zerumbone에 의해 억제됨도 보고 되었다[14].

본 연구는 염증반응, 암세포를 비롯한 면역세포에 다양한 기 능을 나타내는 zerumbone이 단구의 유주에 어떠한 영향을 미 치는지 알아보고자 진행되었다. 먼저 $\mathrm{MCP}-1$ 에 의해 단구세포 주 THP- 1 의 유주가 $\mathrm{MCP}-1$ 에 의해 유발되는 것을 확인하였으 며, $\mathrm{MCP}-1$ 에 의해 유발된 유주는 zerumbone에 의해 감소되 었다. MCP-1 처리 후 감소하는 cAMP는 zerumbone에 의해 다시 증가하였고, $\mathrm{MCP}-1$ 에 의해 유도되었던 Erk 인산화는 zerumbone에 의해 감소되었다. 이와 같은 결과를 토대로 zerumbone을 통한 단구의 유주 조절 가능성을 제시하고자 한다.

\section{재료 및 방법}

\section{1. 시약}

본 연구에서 사용된 시약은 Zerumbone (Sigma-Aldrich, St. Louis, MO, USA)와 Recombinant human CCL2 (MCP-1,
BioLegend, San Diego, CA, USA)이다.

\section{2. 세포 및 세포배양}

사용한 세포는 사람 단핵구세포주인 THP-1세포(Korean Cell Line Bank, Seoul, Korea) 이다. 세포배양액은 Roswell Park Memorial Institute (RPMI) 1640 medium with L-glutamine (Lonza, Walkersvill, MD, USA)에 10\%(v/v) Fetal bovine serum (FBS) (Gibco, Grand Island, NY, USA), 1\%(v/v) Penicillin/Streptomycin (Gibco, Grand Island, NY, USA), 1\%(v/v) 4-(2-hydroxyethyl)-1-piperazineethanesulfonic acid (HEPES) (Welgene, Daegu, Korea), 1\%(v/v) nonessential amino acid (Welgene, Daegu, Korea)를 첨가하여 사용하였다. 배양은 $37^{\circ} \mathrm{C}, 5 \% \mathrm{CO}_{2}$ 조건을 맞춘 배양기를 이용 하여 진행하였다.

\section{Transwell migration assay}

세포 유주 평가를 위해 $5 \mu \mathrm{m}$ pore size의 falcon cell culture inserts (Corning Co., NY, USA)와 24 wells 짜리 falcon companion tissue culture plate (Corning Co., NY, USA)를 사용하였다. 실험은 migration buffer (RPMI 1640, $10 \mathrm{mM}$ $\mathrm{HEPES}, \mathrm{pH} 7.4,0.1 \% \mathrm{BSA}$ )를 이용하여 진행하였고, 실험 전 세 포는 migration buffer와 함께 $37^{\circ} \mathrm{C}, 5 \% \mathrm{CO}_{2}$ 환경에서 overnight starvation 과정을 거쳤다. 이후 조건 당 $2 \times 10^{5}$ 의 THP-1 세포를 $200 \mu \mathrm{L}$ 의 migration buffer에 섞어 insert에 넣 고, underwell에는 MCP-1이 첨가된 migration buffer $600 \mu \mathrm{L}$ 를 넣었다. 준비된 insert를 각 underwell에 삽입하고 $37^{\circ} \mathrm{C}$, $5 \% \mathrm{CO}_{2}$ 환경에서 배양하였다. 배양 후에 insert를 제거하고 underwell로 이동한 세포들을 trypan blue를 이용하여 염색 계수 하였다.

\section{CAMP 분비량 측정}

THP-1 세포주를 96 well plate에 $2 \times 10^{5}$ cells/well 로 seeding 후 조건별로 MCP-1과 zerumbone을 처리하였다. 4시 간 후 96 well plate를 원심분리 하고 상층액을 얻어 cAMP 측정 용 ELISA kit (Cell Biolabs, San Diego, CA, USA)를 이용하여 $\mathrm{CAMP}$ 를 정량하였다. 제조사의 측정 방법에 의거 실험을 진행 하였다.

\section{Western blot을 통한 단백질양 및 인산화정도 분석}

THP-1 세포주를 $60 \mathrm{~mm}$ 배양 접시에 $2 \times 10^{6}$ cells/well로 seeding 후 $\mathrm{MCP}-1$ 을 $100 \mathrm{ng} / \mathrm{mL}$ 농도로, zerumbone을 다양 
한 농도 $(1,5,10,50 \mu \mathrm{M})$ 로 2 시간 동안 처리해 주었다. PBS로 2회 세척한 후 lysis buffer를 이용해 세포를 용해시키고 19,000 $\times \mathrm{g}, 4^{\circ} \mathrm{C}$ 에서 10 분간 원심분리하여 단백질을 추출하였다. 단 백질의 농도는 Lowry protein assay kit (Bio-Rad, Hercules, $\mathrm{CA}, \mathrm{USA}$ )를 이용해 정량하였고, $30 \mu \mathrm{g}$ 의 단백질을 $10 \% \mathrm{acry}-$ lamide gel에서 전기영동하여 분리하였다. 분리된 단백질은 nitrocellulose membrane에 transfer하고 5\% skim milk를 이 용해 실온에서 1 시간 blocking 후 각각 pErk1/2, Erk, $\beta$-actin 에 특이적인 1차 항체를 희석하여 $4^{\circ} \mathrm{C}$ 에서 overnight 동안 반 응시켰다. 1차 항체와 반응이 끝나면 3회 세척 후 2차 항체와 실 온에서 2시간 동안 반응 시키고, 다시 3회 세척한 후 ECL kit (Thermo, Waltham, MA, USA)와 반응시켜 X-ray film을 이용 해 단백질의 양 및 인산화 정도를 측정하였다.

\section{6. 통계분석}

실험결과는 mean $\pm \mathrm{SD}$ 로 표현하였다. $\mathrm{ANOVA}$ 를 이용한 Student t-test를 통해 $P<0.05$ 이하인 경우를 유의한 것으로 판정하였다.

\section{결 과}

\section{MCP-1에 대한 THP-1 세포 유주 유도 확인}

Transwell assay system을 통해 다양한 농도의 MCP-1 (0, $10,50,100,200,500 \mathrm{ng} / \mathrm{mL}$ ) 처리 후 THP-1의 유주 현상이 유발됨을 확인하였다(Figure 1). $10 \mathrm{ng} / \mathrm{mL}$ 의 MCP-1 처리 시 이미 5배 이상의 세포가 underwell로 이동하였다. 100, 200 $\mathrm{ng} / \mathrm{mL}$ 의 MCP-1 처리 시 유주 세포 수가 약간 상승하였고,

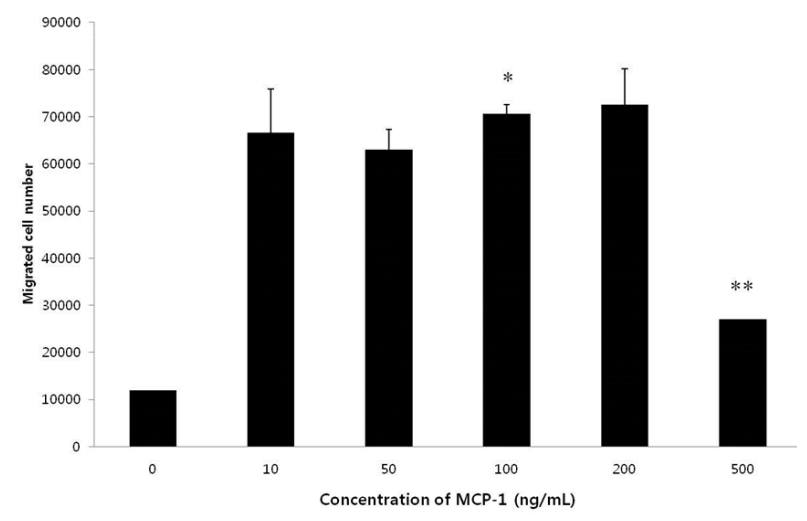

Figure 1. THP-1 cell migration after MCP-1 treatmnet. THP-1 cells are incubated with various concentrations of $\mathrm{MCP}-1(0,10,50$, $100,200,500 \mathrm{ng} / \mathrm{mL}$ ) for $4 \mathrm{hr}$. After incubation, the cells having migrated to the underwells were counted through trypan blue exclusion counting method. Values present mean \pm SD of three separate experiments $\left({ }^{\star} P<0.05\right.$, $\left.{ }^{\star \star} P<0.01\right)$.
$500 \mathrm{ng} / \mathrm{mL}$ 를 처리했을 경우에는 감소하였다.

\section{Zerumbone에 의한 세포 유주 감소}

$\mathrm{MCP}-1$ 에 의해 유도된 세포 유주가 zerumbone에 의해 감소 하였다(Figure 2). MCP-1과 함께 다양한 농도(10, 100, 500, $1000 \mathrm{nM})$ 의 zerumbone을 동시에 처리해 주고 4시간 후에 underwells로 이동한 세포를 계수하였다. $10 \mathrm{nM}$ zerumbone 을 처리해 주었을 때 약 $30 \%$ 의 유주가 감소했으며, $100 \mathrm{nM}$ zerumbone 처리 시 $50 \%$ 이상의 강한 유주 감소 현상이 나타났 다. $500 \mathrm{nM}$ zerumbone 처리 시에는 $100 \mathrm{nM}$ zerumbone을 처리했을 때와 비슷한 정도의 유주 감소가 나타났다.

\section{Zerumbone에 의한 CAMP 발현 강화}

Zerumbone 및 MCP-1 처리 시, cAMP 발현 변화를 발색반 응 측정 원리에 기반한 ELISA kit를 이용하여 측정·분석 하였다. $2 \times 10^{5} /$ well의 THP- 1 세포를 zerumbone, MCP- 1 단독 처리 혹은 동시 처리하여 4 시간 배양 후 원심 분리 하여 상층액을 얻 었다. ELISA kit 제조사의 실험방법에 따라 상층액 내의 cAMP 농도를 측정하였다. 어떠한 시약으로도 처리하지 않았을 때에 는 약 $70 \mathrm{ng} / \mathrm{mL}$ 의 cAMP가 측정되었고, zerumbone 단독으로 처리해 주었을 때에는 $95 \mathrm{ng} / \mathrm{mL}$ 로 증가하였음을 확인하였다. 반면에 MCP-1 단독으로 처리해 주었을 때에는 CAMP 농도가 $45 \mathrm{ng} / \mathrm{mL}$ 로 감소하였다. MCP-1 단독 처리에 의한 CAMP의 감소는 zerumbone을 같이 처리해 주었을 경우 $80 \mathrm{ng} / \mathrm{mL}$ 정도 로 다시 상승하였다(Figure 3).

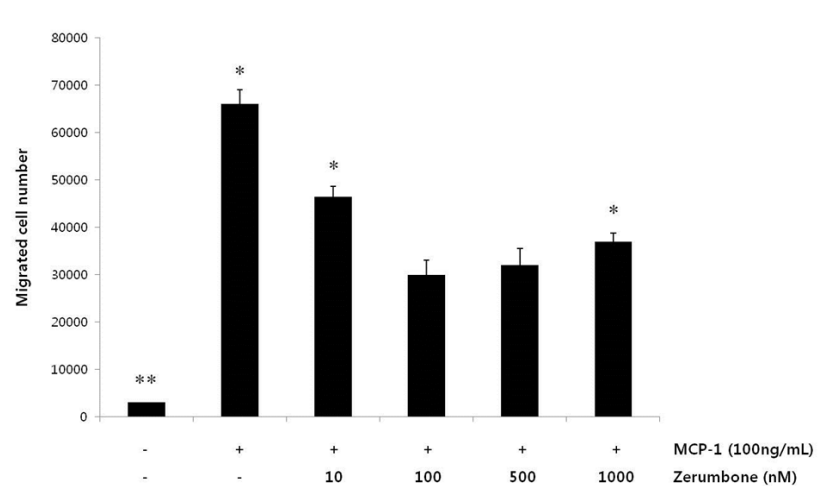

Figure 2. Inhibition of MCP-1 induced THP-1 migration by zerumbone. THP-1 cells are incubated with or without MCP-1 $(100 \mathrm{ng} / \mathrm{mL})$. The cells incubated with $M C P-1$ are simultaneously treated with various concentrations of zerumbone (0,10, 100, 500, $1000 \mathrm{nM})$. After $4 \mathrm{hr}$ of incubation, the cells of underwells were counted through trypan blue exclusion counting method. Values present mean \pm SD of three separate experiments $\left({ }^{\star} P<0.05,{ }^{\star \star} P<0.01\right)$. 


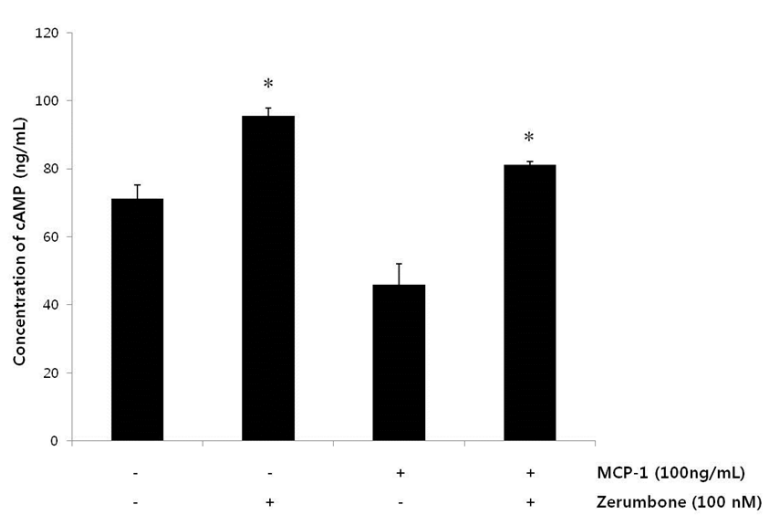

Figure 3. Increase of CAMP expressions after treatment of zerumbone. THP-1 cells were incubated with zerumbone, MCP-1, and both reagents for $4 \mathrm{hr}$. After culturing, supernatant was obtained and CAMP concentration was measured. Values present mean \pm SD of three separate experiments $\left({ }^{\star} P<0.05,{ }^{\star *} P<0.01\right)$.

\section{Zerumbone에 의한 Erk 단백질의 인산화 감소}

Erk 단백질의 인산화 정도는 세포 단독 조건과 zerumbone 단독 처리 조건에서 변화가 없었으나, $\mathrm{MCP}-1$ 을 단독으로 처리 해 주었을 때 증가하였다(Figure 4). 그러나, zerumbone을 $\mathrm{MCP}-1$ 과 동시에 처리해 주었을 때에는 다시 세포 단독 조건 혹 은 zerumbone 단독 조건과 비슷한 수준으로 감소하였다. Erk 단백질 자체의 양은 $\mathrm{MCP}-1$, zerumbone 단독 처리 혹은 동시 처리 조건에서 변화가 없었다. 대조 단백질인 $\beta$-actin의 양도 의미있는 변화를 나타내지 않았다.

\section{고 찰}

단구는 골수 유래 세포로써 혈행을 따라 신체를 돌다가 조직 과 림프기관으로 이동한다. 그곳에서 대식세포 혹은 특이 수지 상세포들로 분화하는 특성을 지닌다[15]. 일상적인 조건하에서 조직으로 이동한 경우 조직 내 대식세포 수를 보충해 주는 역할 을 하지만, 염증에 대한 반응으로 조직으로 이동한 경우에는 면 역 반응 및 염증 반응에 참여하는 역할을 하게 된다. 단구와 기타 면역 세포들의 조직 내 이동현상은 화학주성을 일으키는 케모 카인(chemokines)을 통해 유발된다. 이 화학주성은 G-단백결 합케모카인수용체(G protein-coupled chemokine receptors, $\mathrm{GPCR})$ 와 하부 신호전달 과정의 활성화를 통해 진행된다. 염증 이 일어난 조직으로 이동하는 단구들은 CC chemokine family receptor 2 (CCR2)를 많이 발현하고 있다. CCR2는 염증반응 중 높게 발현되는 $\mathrm{MCP}-1$ 과 결합하는 수용체다[16]. MCP-1에 의해 유발되는 단구의 유주 현상은 염증에 대한 적절한 면역반 응의 발현을 위해서 중요한 의미를 지니지만, 여러 염증 질환의

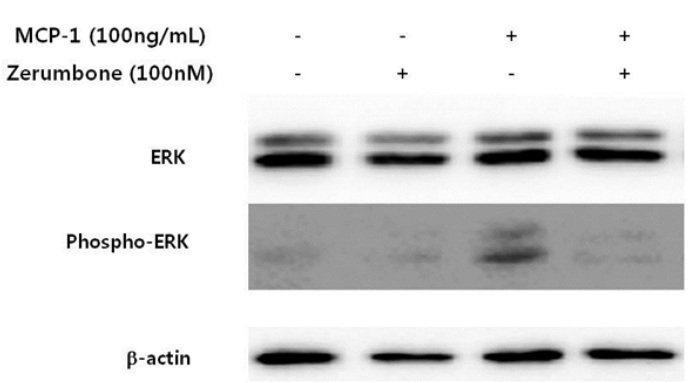

Figure 4. Decrease of phosphrylation of Erk induced by MCP-1 after treatment of zerumbone. Changes in the phosphorylation patterns of Erk proteins after zerumbone and MCP-1 treatment were analyzed. Phosphorylation of Erk was increased by MCP-1 and was decreased when MCP-1 and zerumbone were simultaneously treated. Zerumbone treatment alone doesn't induce the phosphorylation.

진행에 연관되어 있다. 특히 죽상동맥경화 플라크 형성 및 질병 진행과단구간의 관계는 널리 알려져 있다[1]. 이에 단구의 유주 현상을 조절하는 방식으로 죽상동맥경화증을 예방-치료할 가 능성을 생각해 볼 만 하다.

이러한 배경으로, 본 연구는 zerumbone이 MCP-1에 의해 유도된 유주 현상에 미치는 영향에 대해 알아보고자 진행되었 다. Zerumbone은 야생 생강의 일종인 Zingiber zerumbet Smith의 주요 생물 활성 성분이다. 실험에 사용된 THP-1 세포 는 급성 단핵구성 백혈병 세포에서 유래한 세포주로써 단핵구 의 기능, 기능 기전, 신호전달과정, 단핵구 및 대식세포 기능 등 다양한 단핵구 관련 연구에 널리 사용되고 있다[17]. 우선적으 로, $\mathrm{MCP}-1$ 에 의해 THP-1의 유주가 발생하는지 여부를 알아보 았다. $500 \mathrm{ng} / \mathrm{mL}$ 농도를 제외하고, 처리해 준 모든 농도의 $\mathrm{MCP}-1$ 에 의해 유주 현상이 발생한 것을 확인하였다(Figure 1). Transwell assay system 을사용하였고, 4시간 배양 후 underwell 로 이동한 THP-1세포의 수를 trypan blue를 이용하여 계수하 였다. 가장 강한 유주현상을 유발한 $\mathrm{MCP}-1$ 의 농도는 200 $\mathrm{ng} / \mathrm{mL}$ 이지만, 오차 범위와 시약준비의 용이성 등을 고려해 이 후의 모든 실험에 $100 \mathrm{ng} / \mathrm{mL}$ 의 농도를 사용하였다.

다음으로 zerumbone 이 유주 현상에 미치는 영향을 알아보 기 위해 transwell assay 중 다양한 농도의 zerumbone을 처리 해 주었다. MCP-1 (100 ng/mL)을 단독으로 처리해 준 조건에 서 이동한 세포의 수를 기준으로 각 농도 별 zerumbone 처리 후 이동 세포수의 백분율을 구하는 방식으로 정량 하였다. MCP-1 과 zerumbone을 동시에 처리해 주었을 경우, 처리한 모든 농도 의 zerumbone 이 유주 현상을 감소시켰음을 확인하였다 (Figure 2). $10 \mathrm{nM}$ 의 농도에서 이미 30\% 감소를 나타냈으며, $100 \mathrm{nM}$ 과 $500 \mathrm{nM}$ 에서 50\% 이상의 강한 감소를 나타냈다. 
$1000 \mathrm{nM}$ 에서는 유주 현상이 다소 증가하는 양상을 관찰하였다. 이러한 zerumbone의 유주 현상 감소 기능이 어떻게 나타나 는 가를 알아보기 위해 cyclic adenosine monophosphate (cAMP) 분비량과 Erk 단백질의 인산화 변화 양상을 분석하였 다. CAMP는 MCP-1의 수용체인 CCR2 신호전달 과정 중 중요 한 세포 내 2차 전달자 중 하나이다[18]. cAMP 측정을 위해 THP-1 세포를 zerumbone, MCP-1 각각 단독으로 처리해 준 조건, 두 시약을 동시에 처리해 준 조건의 배양액 내 cAMP 농도 를 측정하였다(Figure 3). 세포 단독으로 배양해 주었을 때에 비 해서, zerumbone 단독 처리 시 배양액 내 cAMP 의 농도가 $30 \%$ 이상 증가하였다. MCP-1 단독 처리 시에는 비슷한 정도로 감소 한 것을 확인할 수 있었다. 그러나, $\mathrm{MCP}-1$ 과 zerumbone을 동 시에 처리해 주었을 때 cAMP의 농도는 다시 크게 상승하였다. 이 같은 cAMP의 상승은 zerumbone 단독 처리 시 정도는 미치 지 못했으나, MCP-1 처리에 의한 $\mathrm{AMP}$ 감소 효과를 충분히 극 복하고 남을 정도의 효과로 보여진다. 다음으로, 대표적인 MCP-1 유발 THP-1 신호전달 단백질 Erk의 인산화 경향 변화 를 살펴보았다[19]. Zerumbone만 처리해 주었을 때는 아무것 도 처리하지 않은 상태의 Erk 인산화 정도가 관찰되었다(Figure 4). MCP- 1 을 단독으로 처리해 준 경우에는 분명한 Erk의 인산 화가 관찰되었고, $\mathrm{MCP}-1$ 과 zerumbone을 동시에 처리해 준 경우에는 다시 인산화 정도가 감소하였다.

본 연구는 zerumbone이 단핵구 세포주인 THP-1 세포의 유 주 현상을 억제할 수 있음을 시사한다. 유주 현상 유발을 위해 사 용한 MCP-1은 염증 반응 시 발현·분비되는 대표적인 케모카인 으로써, 이미 많은 연구를 통해 죽상동맥경화 시 증가하여 단구 의 이동과 지방 축적을 유도한다는 사실이 알려져있다[1]. 그러 므로, 본 연구결과는 zerumbone을 이용한 죽상동맥경화 플라 크 형성 및 질환 발전을 감소 가능성을 보여준다. 이를 위해 우선 사람의 혈액에서 분리한 단구를 이용하여 zerumbone의 기능 을 확인해야 할 필요가 있다. 나아가 동물질환모델을 이용하여 zerumbone의 효과를 확인해야 할 것이다. 또한 zerumbone의 작용 기전을 밝히기 위해 보다 자세한 생화학적 연구가 필요하 다. MCP-1은 염증과 면역반응 과정에서 중요한 기능을 나타내 는데, 특히 죽상동맥경화증과 연관된 심혈관 질환의 초기, 후기 에 연관되어 있는 것으로 알려져 있다[20]. MCP-1 단독 처리 후 감소한 cAMP의 농도는 zerumbone 처리를 통해 다시 상승하 였는데, 이에 대한 자세한 기전 연구가 필요하다. CAMP에 의해 활성이 증가되는 cAMP-dependent protein kinase A (PKA) 의 활성을 측정하는 것도 가능하다. 또한, CAMP와 Erk 인산화 간의 관계를 보다 명확하게 분석해야 하며, CCR2와 같은
$\mathrm{GPCR}$ 신호전달과정의 다른 분자들의 활성이 zerumbone에 의해 어떠한 영향을 받는지 분석해 봐야 할 것으로 생각된다.

\section{요 약}

본 연구는 zerumbone이 단구의 유주에 어떠한 영향을 미치 는지 알아보고자 진행되었다. 단구는 다양한 염증 질환의 중요 한 매개자로 인식되고 있으며, 활성, 유주 등 단구의 기능 조절 을 통해 염증 질환을 조절하는 가능성이 보고 되고 있다. 염증 발 생 시 증가하는 케모카인인 $\mathrm{MCP}-1$ 에 의해 단핵구 세포주 THP-1의 유주가 유발되는 것을 확인하였다. $10 \mathrm{ng} / \mathrm{mL}$ 의 농도 에서 유주가 발생하였으며, $100 \mathrm{ng} / \mathrm{mL}$ 과 $200 \mathrm{ng} / \mathrm{mL}$ 의 농도 에서 가장 높은 유주 현상이 나타났다. $\mathrm{MCP}-1$ 에 의해 유발된 THP-1 유주는 zerumbone 존재 시 50\% 이상 감소하였다. $\mathrm{MCP}-1$ 수용체인 CCR2 신호전달 과정의 중요 2차 전달자인 cAMP 의 배양액 내 농도는 zerumbone 단독 처리 시 세포 단독 배양 조건에 비해 증가하였으며, $\mathrm{MCP}-1$ 단독 처리 시에는 의미 있게 감소하였다. 그러나, zerumbone과 MCP-1을 동시에 처 리했을 때에는 다시 CAMP의 증가가 관찰되었다. MCP-1 처리 에 의해 일어나는 Erk 인산화도 zerumbone과 동시 처리 시 감 소하는 결과를 확인했다. 본 연구는 염증성 질환에 중요한 매개 자로 인식되고 있는 단구의 유주 현상을 조절하는 zerumbone 의 가능성을 보여준다.

Acknowledgements: This paper was supported by the Semyung University Research Grant of 2015.

Conflict of interest: None

\section{REFERENCES}

1. Gautier EL, Jakubzick C, Randolph GJ. Regulation of the migration and survival of monocyte subsets by chemokine receptors and its relevance to atherosclerosis. Artherioscler Thromb Vasc Biol. 2009;29:1412-1418.

2. Murakami A, Ohigashi H. Cancer-preventive anti-oxidants that attenuate free radical generation by inflammatory cells. Biol Chem. 2006;387:387-392.

3. Sulaiman MR, Perimal EK, Akhtar MN, Mohamad AS, Khalid MH, Tasrip NA, et al. Anti-inflammatory effect of zerumbone on acute and chronic inflammation models in mice. Fitoterapia. 2010;81:855-858.

4. Perimal EK, Akhtar MN, Mohamad AS, Khalid MH, Ming OH, Khalid S, et al. Zerumbone-induced antinociception: involvement of the L-arginine-nitric oxide-cGMP -PKC-K+ ATP channel pathways. Basic Clin Pharmacol Toxico. 2011;1108: 
155-162.

5. Keong YS, Alitheen NB, Mustafa S, Abdul Aziz S, Abdul Rahman M, Ali AM. Immunomodulatory effects of zerumbone isolated from roots of Zingiber zerumbet. Pak J Pharm Sci. 2010; 23:75-82.

6. Kitayama T, Iwabuchi R, Minagawa S, Shiomi F, Cappiello J, Sawada S, et al. Unprecedented olefin-dependent histidinekinase inhibitory of zerumbone ring-opening material. Bioorg Med Chem Lett. 2004;23:5943-5946.

7. Eguchi A, Kaneko Y, Murakami A, Ohigashi H. Zerumbone suppresses phorbol ester-induced expression of multiple scavenger receptor genes in THP-1 human monocytic cells. Biosci Biotechnol Biochem. 2007;71:935-945.

8. Sulaiman MR, Perimal EK, Zakaria ZA, Mokhtar F, Akhtar MN, Lajis $\mathrm{NH}$, et al. Preliminary analysis of the antinociceptive activity of zerumbone. Fitoterapia. 2009;80:230-232.

9. Taha MM, Abdul AB, Abdullah R, Ibrahim TA, Abdelwahab SI, Mohan S. Potential chemoprevention of diethylnitrosamineinitiated and 2-acetylaminofluorene-promoted hepatocarcinogenesis by zerumbone from the rhizomes of the subtropical ginger (Zingiber zerumbet). Chem Biol Interact. 2010;186: 295-305.

10. Shanmugam MK, Rajendran P, Li F, Kim C, Sikka S, Siveen KS, et al. Abrogation of STAT3 signaling cascade by zerumbone inhibits proliferation and induces apoptosis in renal cell carcinoma xenograft mouse model. Mol Carcinog. 2015;54:971-985.

11. Zhang S, Liu Q, Liu Y, Oiao H, Liu Y. Zerumbone, a Southeast Asian ginger sesquiterpene, induced apoptosis of pancreatic carcinoma cells through p53 signaling pathway. Evid Based Complement Alternat Med. 2012;2012:936030.

12. Murakami A, Hayashi R, Tanaka T, Kwon KH, Ohigashi H, Safitri R. Suppression of dextran sodium sulfate-induced colitis in mice by zerumbone, a subtropical ginger sesquiterpene, and nimesulide: separately and in combination. Biochem Pharmacol. 2003;66:1253-1261.

13. Murakami A, Song M, Katsumata S, Uehara M, Suzuki K, Ohigashi H. Citrus nobiletin suppresses bone loss in ovariectomized ddY mice and collagen-induced arthritis in DBA/1J mice: possible involvement of receptor activator of NF-kappaB ligand (RANKL)-induced osteoclastogenesis regulation. Biofactors. 2007;30:179-192.

14. Moon C. Zerumbone's effects on jurkat cell proliferation and migration. Korean J Clin Lab Sci. 2015;47:182-187.

15. Tacke F, Randolph GJ. Migratory fate and differentiation of blood monocyte subsets. Immunobiology. 2006;211:609-618.

16. Geissmann F, Jung S, Littman DR. Blood monocytes consist of two principal subsets with distinct migratory properties. Immunity. 2003;19:71-82.

17. Chanput W, Mes J, Vreeburg RAM, Savelkoul HFJ, Wichers HJ. Transcription profiles of LPS-stimulated THP-1 monocytes and macrophages: a tool to study inflammation modulating effects of food-derived compounds. Food \& Function. 2010;1: 254-261.

18. Walther C, Ferguson SSG. Minireview: role of intracellular scaffolding proteins in the regulation of endocrine $G$ protein-coupled receptor signaling. Mol Endocrinol. 2015;29: 814-830.

19. Carmen Jimenez-Sainz M, Fast B, Mayor F, Aragay AM. Signaling pathways for monocyte chemoattractant protein 1-mediated extracellular signal-regulated kinase activation. Mol Pharmacol. 2003;64:773-782.

20. Bianconi V, Sahebkar A, Atkin SL, Pirro M. The regulation and importance of monocyte chemoattractant protein-1. Curr Opin Hematol. 2017;24:1-8. 